\title{
Interaction of Neisseria gonorrhoeae with Classical Complement Components, C1-Inhibitor, and a Monoclonal Antibody Directed against the Neisserial H.8 Antigen
}

\author{
Jo E. Schweinle, ${ }^{\star \$}$ Penny J. Hitchcock, ${ }^{\star}$ Andrea J. Tenner," Carl H. Hammer, ${ }^{\star}$ Michael M. Frank, and Keith A. Joiner* \\ ${ }^{*}$ Laboratory of Clinical Investigation and ${ }^{\ddagger}$ Laboratory of Microbial Structure and Function, National Institute of Allergy and Infectious \\ Diseases, National Institutes of Health, Bethesda, Maryland 20892; §University of Texas Medical Branch at Galveston, Texas,
} Galveston, Texas 77550; and "American Red Cross, Rockville, Maryland 20855

\section{Abstract}

Strains of Neisseria gonorrhoeae were used to evaluate bactericidal and opsonic properties of McAb 10 directed against the Neisserial outer membrane antigen, H.8. Gonococci were either serum resistant in the absence but serum sensitive in the presence, of McAb 10, or serum sensitive or serum resistant regardless of the presence of McAb 10 . Strain JS3, which fell in the former category, was used in subsequent studies.

C1 zymogen formed by reassociation of isolated $\mathrm{C} 1$ subunits was not directly activated by JS3 in the presence or absence of C1-inhibitor. JS3 thus was unable to directly activate the classical pathway independently of antibody.

When purified classical pathway components were used to deposit C3 on JS3 in the absence of serum regulatory proteins or antibodies, added $\mathrm{C} 1$-inhibitor reduced $\mathrm{C} 3$ binding to background levels. When McAb 10 was present, $\mathrm{C} 3$ binding was unaffected by $\mathrm{C} 1$-inhibitor.

Covalently bound, large molecular weight $\mathrm{C} 3 \alpha$-chain-gonococcal complexes were disbanded by methylamine release of ester linkages. Released ${ }^{125} \mathrm{I}-\mathrm{C} 3$ migrated as $\mathrm{C} 3 \mathrm{~b}$ without degradation by gonococcal proteases.

Purified classical components alone or McAb 10 alone facilitated JS3 killing by neutrophils; when combined, the two provided maximal killing. Levels of McAb 10 that only slightly increase C3 deposition on JS3 are bactericidal in serum and maximally opsonic in combination with purified classical pathway components.

\section{Introduction}

Serum bactericidal activity against Neisseria gonorrhoeae is primarily associated with classical complement pathway activation (1-5). Although an antibody requirement for lytic activity of serum against clinical isolates of $N$. gonorrhoeae has been suggested, this presumption has not been rigorously tested.

Selected mutants of gram-negative enteric organisms directly activate the classical complement pathway in vitro in the absence of antibody (6-9). The initiating event is conversion of

Dr. Hitchcock's present address is Department of Microbiology and Immunology, University of Tennessee, Memphis, TN 38164. Address reprint requests to Dr. Jo E. Schweinle, Laboratory of Parasitic Diseases, National Institute of Health, Bldg. 4, Room 126, Bethesda, MD 20892.

Received for publication 25 July 1988

The Journal of Clinical Investigation, Inc.

Volume 83, February 1989, 397-403 zymogen $\mathrm{Cl}$ to its active serine esterase form (reviewed in references 10 and 11) upon interaction of $\mathrm{Cl}$ with constituents of the bacterial outer membrane. This activation is not abrogated by the serum glycoprotein, $\mathrm{Cl}$-inhibitor, if $\mathrm{C} 1$ interacts with rough bacteria containing (truncated) LPS, but the reaction is totally inhibited on the surface of organisms bearing smooth (complete) LPS $(6,9) . N$. gonorrhoeae contains LPS bearing only a limited number of core sugar residues $(12,13)$, suggesting that this organism may directly activate $\mathrm{Cl}$ even in the presence of $\mathrm{Cl}$-inhibitor.

This issue has been examined to a limited extent with gonococci during incubation in serum. Harriman and colleagues (14) showed activation of purified, radiolabeled C1s in serum during incubation with various serum-sensitive and -resistant gonococci. Shafer and co-workers (4) showed C1 consumption from agammaglobulinemic serum by a serumsensitive mutant of $N$. gonorrhoeae with "deep rough" LPS. Nonetheless, no studies have been done with $N$. gonorrhoeae using purified complement components to exclude definitively the contribution of antibody to the observed results. Two issues thus remain unsettled: whether complement is activated in the absence of antibody and, if so, whether activation takes place in the presence of $\mathrm{Cl}$-inhibitor.

Recently, H.8 antigen, common to $N$. gonorrhoeae and Neisseria meningitidis, has been defined based on its reactivity with several independently derived MAb (15-18). H.8 is interesting for several reasons: $(a)$ it has a common, antigenically invariant epitope that is immunoaccessible on viable bacteria in vitro and in vivo $(16,19-21) ;(b)$ the antigen $(15,16)$ and the gene (22) appear to be restricted to the pathogenic (and opportunistic) members of the genus; $(c)$ the $\mathrm{H} .8$ antigen gene contains a repetitive 15 -bp sequence constituting $>90 \%$ of the structural gene (23), six copies of which are found in another virulence-associated gene, the azurin gene $(24,25)$; and $(d)$ H.8 appears to be a lipoprotein, the first described in Neisseria species, and may be important in membrane architecture and integrity. Finally, the H.8 antigen is immunogenic in humans: H.8-specific antibody responses have been detected in patients with local and disseminated gonococcal and meningococcal disease $(26,27)$. The contribution of H.8-specific antibody to serum opsonic and bactericidal activity against $N$. gonorrhoeae is, therefore, of interest.

In this report, we studied bactericidal and opsonic activities of $\mathrm{McAb}$ 10, directed against the $\mathrm{H.8}$ antigen. Our results indicate that $\mathrm{McAb} 10$ is bactericidal for some but not all strains of gonococci during incubation in adsorbed normal human serum. We also show that the serum-resistant clinical isolate JS3 does not directly activate $\mathrm{C} 1, \mathrm{C} 4, \mathrm{C} 2$, and $\mathrm{C} 3$ independently of antibody, but rather accepts $\mathrm{C} 3 \mathrm{~b}$ deposition resulting from spontaneous, autocatalytic activation of $\mathrm{C} 1$. We 
demonstrate that $\mathrm{C} 1$-inhibitor blocks autoactivation, and that $\mathrm{McAb} 10$ induces activation of $\mathrm{Cl}$ which is not abrogated by $\mathrm{Cl}$-inhibitor, thereby enhancing phagocytosis and killing of gonococci by PMN. These experiments are the first to examine rigorously the contribution of antibody to complement activation by $N$. gonorrhoeae and to examine the opsonic and bactericidal function of an H.8-reactive MAb.

\section{Methods}

Buffers and reagents. HBSS containing $1 \mathrm{mM} \mathrm{MgCl} 2$ and $0.15 \mathrm{mM}$ $\mathrm{CaCl}_{2}$ (HBSS ++$)^{1}$ was the standard buffer in these experiments. In some cases, $0.1 \%$ gelatin (Sigma Chemical Co., St. Louis, MO) or $1 \%$ BSA (immunoglobulin- and fatty acid-free, Boehringer Mannheim Biochemicals, Indianapolis, IN) was added to HBSS ++ (HBSS++GEL; HBSS++ALB). All reagents were brought to room temperature before use.

Serum. Pooled normal human serum (PNHS) was obtained from five normal volunteers with no history of previous gonococcal infections. Serum was adsorbed twice against homologous glutaraldehydefixed $N$. gonorrhoeae to remove natural antibody, as previously described (28). Serum adsorbed by this procedure lost $<25 \%$ of hemolytic C3 activity measured as described (29). Aliquots were stored at $-70^{\circ} \mathrm{C}$.

Bacteria. Gonococcal strains used in these experiments are listed in Table I. All strains were tested in the serum bactericidal assays; JS3 was studied in all experiments.

Bacteria were grown on gonococcal agar base (National Institutes of Health Media Room) with $1 \%$ Isoyitalex (Becton Dickinson \& Co., Inc., Cockeysville, MD) in candle extinction jars at $37^{\circ} \mathrm{C}$. Transparent, nonpiliated colonies were passed daily. Colony phenotype was determined using the criteria of Swanson (30). For experiments, the bacteria were grown 18-20 h, then suspended in HBSS ++GEL or HBSS++ALB at room temperature to a concentration of $1 \times 10^{8}$ bacteria $/ \mathrm{ml}\left(\mathrm{OD}_{600}=0.100 \mathrm{~nm}\right)$.

$M A b$. MAb 10 directed against Neisserial surface antigen $\mathrm{H} .8$ was prepared as described by Hitchcock et al. (16). Tissue culture supernatant was concentrated 20-fold using a 100-ml cell and PM100 membrane (Amicon Corp., Danvers, MA). A second sample was prepared by growing the monoclone in defined medium containing $\left[{ }^{35} \mathrm{~S}\right]-$ methionine from New England Nuclear, Boston, MA. The culture supernatant fluid was replaced with fresh medium to which $300 \mu \mathrm{Ci}$ of $\left[{ }^{35} \mathrm{~S}\right] \mathrm{L}-$-methionine was added. The culture was incubated at $37^{\circ} \mathrm{C}$ in an atmosphere of $10 \% \mathrm{CO}_{2}$ for $48 \mathrm{~h}$. The cell-free supernatant fluid containing the intrinsically labeled McAb 10 was harvested and used undiluted in experiments in which antibody binding was measured.

Complement components. Guinea pig C1 (GPCl; 10,000 U/ml) was purchased from Cordis Laboratories, Miami, FL. Human C1 subunits $\mathrm{Clq}, \mathrm{Cl}$, and $\mathrm{Cls}$ were purified using the methods of Tenner et al. (31), Ziccardi and Cooper (32), and Valet and Cooper (33), respectively. $5 \mu \mathrm{l} \mathrm{Clq}(2.7 \mathrm{mg} / \mathrm{ml}), 34 \mu \mathrm{l} \mathrm{Cl} \mathrm{r}(187.5 \mu \mathrm{g} / \mathrm{ml})$, and $8 \mu \mathrm{l} \mathrm{Cls}(806$ $\mu \mathrm{g} / \mathrm{ml}$ ) were mixed on ice in $200 \mu \mathrm{l}$ of $1 \%$ ultrapure BSA in distilled water, $100 \mu \mathrm{l}$ of $0.05 \mathrm{M} \mathrm{CaCl}_{2}$, and $815 \mu \mathrm{l} \mathrm{HBSS++GEL}$. The mixture was incubated at $30^{\circ} \mathrm{C}$ for $15 \mathrm{~min}$ with shaking to allow association of $\mathrm{Cl}$ subunits. This mixture ( $150 \mu \mathrm{l} /$ tube $)$ was used in the assays to achieve a final concentration of complement components equivalent to $5 \%$ normal serum concentration. Functionally active human $\mathbf{C 3}$ and $\mathrm{C} 4$ were purified using the procedure of Hammer et al. (34), with minor modifications. C3 was radiolabeled with ${ }^{125}$ ( $\left({ }^{125} \mathrm{IC} 3\right)$ using Iodobeads from Pierce Chemical Co., Rockford, IL. C1-inhibitor was isolated according to previously published methods (35). Human C2 was prepared by a new procedure using polyethylene glycol precipitation, C4b/iC4b Sepharose, and DEAE Sepharose (Pharmacia Fine

1. Abbreviations used in this paper: GPCl, guinea pig $\mathrm{Cl}$; HBSS ++ , HBSS containing $1 \mathrm{mM} \mathrm{MgCl}_{2}$ and $0.15 \mathrm{mM} \mathrm{CaCl}_{2}$.
Chemicals, Piscataway, NJ) (36). All proteins were biochemically pure as assessed by SDS-PAGE and immunoelectrophoresis except C4, which contained small amounts of minor contaminants, but was functionally pure for $\mathrm{C} 4$ hemolytic activity.

Neutrophils. Neutrophils were obtained from normal volunteers with no history of gonococcal infection and who were not taking antibiotics. Lymphocyte Separation Media from Litton Bionetics, Inc. (Charleston, SC) was layered under heparinized blood diluted vol/vol with PBS, then centrifuged for $20 \mathrm{~min}$ at $1,200 \mathrm{rpm}$ at $20^{\circ} \mathrm{C}$. Plasma, platelet, and mononuclear cell supernatant was discarded. Neutrophils were sedimented with $3 \%$ dextran 500 from Pharmacia Fine Chemicals

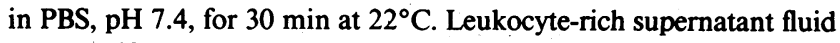
was centrifuged at $1,500 \mathrm{rpm}$ at $4^{\circ} \mathrm{C}$. Contaminating erythrocytes were lysed with cold $0.2 \% \mathrm{NaCl}$ and physiological ionic strength restored by addition of an equal volume of $1.6 \% \mathrm{NaCl}$. After the final centrifugation, the neutrophils were resuspended in HBSS++ALB at a concentration of $5 \times 10^{6} / \mathrm{ml}$.

Serum bactericidal assay. Bacteria were suspended in HBSS++ALB to $\mathrm{OD}_{600}=0.100$ as described above. For presensitization, $100 \mu \mathrm{l}$ of this suspension was mixed with $50 \mu \mathrm{l}$ of dilutions of McAb 10 in buffer, $50 \mu \mathrm{l}$ of an irrelevant MAb or $50 \mu$ l of buffer alone, and the suspension was incubated for $20 \mathrm{~min}$ at $22^{\circ} \mathrm{C}$ with intermittent agitation. Then $100 \mu \mathrm{l}$ of this mixture containing presensitized organisms was added to $100 \mu \mathrm{l}$ of $20 \%$ adsorbed PNHS in HBSS++ALB, and the suspension was incubated at $37^{\circ} \mathrm{C}$ for $60 \mathrm{~min}$. Viable bacteria were enumerated as CFU by making serial dilutions in buffer and plating aliquots on chocolate agar plates (National Institutes of Health Media Room) for growth in candle jars at $37^{\circ} \mathrm{C}$ for $36-48 \mathrm{~h}$. Control samples were handled identically except that presensitized organisms were mixed with $20 \%$ adsorbed PNHS previously heated at $56^{\circ} \mathrm{C}$ for 30 min to block complement activation. $\log _{10}$ kill was calculated for organisms presensitized with McAb 10 or with buffer as previously described (5).

Binding of ${ }^{35}$ S-labeled McAb 10 to JS3. Binding of McAb 10 to strain JS 3 was examined in a quantitative binding assay. Tissue culture supernatant fluids, unlabeled and ${ }^{35} \mathrm{~S}$-intrinsically labeled, were mixed in HBSS ++ GEL. The mixture contained $200 \mu{ }^{35} \mathrm{~S} \mathrm{MCAb} 10$ and increasing amounts of unlabeled McAb 10 ranging from 0 to $320 \mu \mathrm{l}$. Gonococci, strain JS3 ( $1 \times 10^{6}$ in $100 \mu 1$ HBSS + +GEL), were added, and the mixture incubated at $37^{\circ} \mathrm{C}$, tumbling for $1 \mathrm{~h}$. Bacteria were then washed twice with $\mathrm{HBSS}++\mathrm{GEL}$. After the final centrifugation, the bacterial pellet was solubilized in $500 \mu \mathrm{l}$ of $1 \%$ SDS by heating at $100^{\circ} \mathrm{C}$ for $10 \mathrm{~min}$. Samples were then added to scintillation fluid from Hydrofluor; National Diagnostics, Somerville, NJ, and bacteria-associated radioactivity was counted in a liquid scintillation analyzer (2000CA Tri-Carb; Packard Instrument Co., United Technologies, Downers Grove, IL). Results are expressed as counts per minute bound with each concentration of unlabeled McAb 10.

Activation of $\mathrm{Cl}$ by JS3. We next examined whether JS3 directly activated $\mathrm{Cl}^{\prime}$ in the absence of antibody. Deposition of radiolabeled $\mathrm{C} 1 \mathrm{~s}$ within $\mathrm{Cl}$ was measured on JS3 in the presence or absence of $\mathrm{Cl}$-inhibitor. $\mathrm{Clq}(8 \mu \mathrm{g}), \mathrm{Clr}(4.5 \mu \mathrm{g})$, and $\mathrm{Cls}(4.03 \mu \mathrm{g}$ unlabeled and $0.47 \mu \mathrm{g}{ }^{125} \mathrm{I}$ labeled) were mixed at $0^{\circ} \mathrm{C}$ with $15 \mu \mathrm{l}$ veronal buffer, 0.05 $\mathrm{M} \mathrm{CaCl} 2$ (final concentration $2.5 \mathrm{mM} \mathrm{Ca}^{2+}$ ), and $48 \mu \mathrm{H}_{2} \mathrm{O}$ containing $1 \mathrm{mg} / \mathrm{ml}$ ovalbumin from Sigma Chemical Co. C1-inhibitor (13.5 $\mu \mathrm{g})$ was added to the above mixture before aliquots were mixed with JS3 ( $1 \times 10^{7}, 5 \times 10^{7}$, and $1 \times 10^{8}$ organisms). Positive control tubes contained instead of JS3, heat-aggregated human $\operatorname{IgG}\left(63^{\circ} \mathrm{C}, 15 \mathrm{~min}\right.$, $1.16 \mathrm{mg} / \mathrm{ml})$ or $E$. coli $\mathrm{J} 5\left(5 \times 10^{7}\right.$ and $1 \times 10^{8}$ organisms $)$, both of which directly activate $\mathrm{Cl}$ in the presence or absence of $\mathrm{Cl}$-inhibitor $(6,7,37-39)$. Negative control tubes contained $\mathrm{Cl}$ activator components only in the absence of $\mathrm{Cl}$-inhibitor. These mixtures were incubated at $30^{\circ} \mathrm{C}$ for $10 \mathrm{~min}$, and the reaction stopped by addition of SDS-urea-DTT (40). Samples were heated to $37^{\circ} \mathrm{C}$ for $45 \mathrm{~min}$ and SDS-PAGE (8\%) and autoradiography were performed.

Classical complement pathway activation by JS3. Deposition of C3 on strain JS3 was measured during incubation with purified classical pathway components. The final concentration of each component was 
adjusted to $5 \%$ of the antigenic level (for biochemically pure proteins) or $5 \%$ of the hemolytic level (for functionally pure components) of the component in serum. Gonococcal strain JS3 in HBSS++GEL (400 $\mu$, $1 \times 10^{8}$ organisms $/ \mathrm{ml}$ ) was mixed with $20 \mu \mathrm{l} \mathrm{HBSS}++$ GEL or $20 \mu \mathrm{l}$ $\mathrm{McAb}$ 10. The mixture was tumbled end over end at $12 \mathrm{rpm}$ (Rototorque, model 7637; Cole-Parmer Instrument Co., Chicago, IL) at $37^{\circ} \mathrm{C}$ for $10 \mathrm{~min}$. GPCl $(15,000 \mathrm{U})$, human $\mathrm{C} 1(6.8 \mu \mathrm{g}$ in $150 \mu \mathrm{l}$ of HBSS++GEL, $0.005 \mathrm{M} \mathrm{CaCl}_{2}$, and $1 \% \mathrm{BSA}$ ) or $\mathrm{Cl}$ mixed with $\mathrm{Cl}$ inhibitor $(12.5 \mu \mathrm{g})$ were added to JS3 and the mixture incubated at $30^{\circ} \mathrm{C}$ for $15 \mathrm{~min}$ with shaking. The mixtures were centrifuged at $12,500 \mathrm{~g}$ (Eppendorf centrifuge) for $5 \mathrm{~min}$ and the supernatant fluid was discarded. Then classical complement components were added as unlabeled C3 (11.96 $\mu \mathrm{g}),{ }^{125} \mathrm{I}-\mathrm{C} 3(7.82 \mu \mathrm{g}), \mathrm{C} 4(6,000 \mathrm{U})$, and C2 (0.8 $\mu \mathrm{g})$, the final volume was brought to $1 \mathrm{ml}$ with $\mathrm{HBSS}++\mathrm{GEL}$, and the mixture tumbled for $15 \mathrm{~min}$ at $37^{\circ} \mathrm{C}$. Triplicate $200-\mu \mathrm{l}$ aliquots were transferred to microcentrifuge tubes containing $1 \mathrm{ml}$ cold HBSS ++GEL and centrifuged at $12,500 \mathrm{~g}$ for $10 \mathrm{~min}$ at $4^{\circ} \mathrm{C}$. After discarding the supernatant, the sides of the tube were washed with 500 $\mu \mathrm{l} \mathrm{HBSS}++\mathrm{GEL}$, and the pellet was centrifuged again, the supernatant discarded, and the pellet was counted in a gamma scintillation counter from Packard Multi-Prias, Packard Instrument Co. The bacterial pellet was solubilized in SDS sample buffer (41) containing $2 \%$ mercaptoethanol for $10 \mathrm{~min}$ at $100^{\circ} \mathrm{C}$, then frozen at $-70^{\circ} \mathrm{C}$ for subsequent examination by SDS-PAGE.

Form of C3 bound to JS3. The molecular form of ${ }^{125} \mathrm{I}-\mathrm{C} 3$ deposited on the gonococcal surface with purified classical pathway components was examined. Solubilized samples from the $\mathrm{C} 3$ binding experiment were divided in two equal aliquots. To cleave covalent ester linkages between $\mathrm{C} 3$ and acceptor molecules, one aliquot was mixed with $4 \mu \mathrm{l}$ $200 \mathrm{mM}$ methylamine in carbonate buffer at $\mathrm{pH} 11$ and incubated at $37^{\circ} \mathrm{C}$ for $1 \mathrm{~h}$. Then $1.4 \mu \mathrm{l}$ of $0.5 \mathrm{~N} \mathrm{HCl}$ was added to achieve a final $\mathrm{pH}$ 7.8. Aliquots of methylamine- and nonmethylamine-treated samples were applied to a $7.5 \%$ SDS polyacrylamide gel and electrophoresis was performed (41). Autoradiography was done on dried gels.

Killing of JS3 by PMN. Strain JS3 was presensitized with McAb 10 and/or classical complement pathway components exactly as described above in $\mathrm{C} 3$ binding assays. Gonococci $\left(1 \times 10^{7}\right.$ organisms in $100 \mu \mathrm{l} \mathrm{HBSS}++\mathrm{ALB})$ bearing complement components, McAb 10 , or both, were mixed with $2.5 \times 10^{6} \mathrm{PMN}$ in $500 \mu \mathrm{l} \mathrm{HBSS++ALB}$ or HBSS++GEL (JS3/PMN $=4: 1$ ) in microcentrifuge tubes. The volume was brought to $1 \mathrm{ml}$ with $\mathrm{HBSS}++\mathrm{ALB}$, and the mixture was tumbled at $12 \mathrm{rpm}$ at $37^{\circ} \mathrm{C}$. Samples were removed at $0,15,30$, and 60 min, diluted serially in HBSS ++GEL or HBSS++ALB, and duplicate $50-\mu l$ aliquots of each dilution were plated on chocolate agar. CFU were counted on each plate after incubation for $16-20 \mathrm{~h}$ in candle jars at $37^{\circ} \mathrm{C}$. Results at each time period are expressed as percent of the time zero inoculum.

\section{Results}

Bactericidal activity of $M c A b$ 10. All the gonococcal strains characterized in Table I were tested for susceptibility to the bactericidal activity of adsorbed PNHS, alone or with added McAb 10 (Table II). The strains fell into three categories: $(a)$ strains FA 635 and 7189 were sensitive to killing in adsorbed serum, and killing increased slightly with McAb 10 presensitization; (b) strains R11, FA 638, WG, 7220, 7221, and 6305 were resistant to killing in the presence or absence of McAb 10; and $(c)$ strains JS3 and 7122 were serum resistant in the absence of McAb 10, but were serum sensitive when presensitized with McAb 10. In subsequent studies we used strain JS3 because of its differential susceptibility to serum killing in the presence and absence of McAb 10 and because JS3 has been well characterized with respect to outer membrane constituents (42-44).
Table I. Source and Protein I Serogroup of Gonococcal Strains

\begin{tabular}{llc}
\hline Strain & \multicolumn{1}{c}{ Source } & Serogroup* \\
\hline R11 & Milton Tam & IA \\
FA635 & Fred Sparling/Janne Cannon & IA \\
FA638 & Fred Sparling/Janne Cannon & IA \\
JS3 & John Swanson & IA \\
WG & Peter Rice & IB \\
6305 & Leonard Mayer & IA \\
7189 & Leonard Mayer & IB \\
7220 & Leonard Mayer & $\ddagger$ \\
7221 & Leonard Mayer & $\ddagger$ \\
& & \\
\hline
\end{tabular}

* As determined by Dr. J. S. Knapp, University of Washington, Seattle, WA.

$\ddagger$ Transformants made from strains 6305 and 7189 , not serotyped.

Specific binding of McAb 10 to JS3. Experiments were designed to estimate the amount of McAb 10 binding to JS3. Increasing amounts of unlabeled McAb 10 were mixed with a constant amount of ${ }^{35} \mathrm{~S}$-labeled $\mathrm{McAb} 10$ in buffer before gonococci were added. After $60 \mathrm{~min}$ at $37^{\circ} \mathrm{C}$, the organisms were washed and bacteria-associated radioactivity was counted. Results were expressed (Fig. 1) as counts per minute bound at each concentration of added unlabeled antibody. Characteristic of specific binding, as increasing amounts of unlabeled McAb 10 were added, less radioactivity became associated with JS3, reflecting competitive inhibition of $\left[{ }^{35} \mathrm{~S}\right]-$ $\mathrm{McAb} 10$ by unlabeled McAb 10. Furthermore, these results indicate that in the above experiment and in all experiments reported below using 20-50- $\mu$ l volumes of McAb 10 to sensitize JS3 at $1 \times 10^{8} / \mathrm{ml}$, the amounts of antibody bound are below saturating levels.

Activation of $\mathrm{Cl}$ by JS3. C1 zymogen was prepared by mixing $\mathrm{Clq}, \mathrm{Clr}$, and radiolabeled $\mathrm{C} 1 \mathrm{~s}$ at $0^{\circ} \mathrm{C}$, with or without $\mathrm{C} 1$-inhibitor, before adding to $\mathrm{C} 1$ activators or JS3 for incubation at $30^{\circ} \mathrm{C}$. No concentration of JS3 tested in the presence or absence of $\mathrm{Cl}$-inhibitor activated $\mathrm{Cl}$ as determined by absence

Table II. Bactericidal Activity of McAb 10 for 10 Strains of $N$. gonorrhoeae

\begin{tabular}{lrr}
\hline & \multicolumn{2}{c}{$\log _{10}$ kill in $10 \%$ PNHS } \\
\cline { 2 - 3 } Strain & \multicolumn{1}{c}{- McAb10 } & \multicolumn{1}{c}{+ McAb10 } \\
\hline FA635 $(n=3)$ & $2.31 \pm 0.66^{*}$ & $3.19 \pm 1.09$ \\
$7189(n=3)$ & $2.43 \pm 0.15$ & $3.01 \pm 0.21$ \\
R11 $(n=3)$ & $0.31 \pm 0.31$ & $0.22 \pm 0.31$ \\
FA638 $(n=2)$ & $0.03 \pm 0.21$ & $-0.09 \pm 0.10$ \\
WG $(n=3)$ & $0.01 \pm 0.03$ & $-0.02 \pm 0.04$ \\
$7220(n=2)$ & $-0.01 \pm 0.06$ & $0.13 \pm 0.06$ \\
$7221(n=2)$ & $0.10 \pm 0.12$ & $0.09 \pm 0.05$ \\
$6305(n=4)$ & $0.06 \pm 0.09$ & $0.07 \pm 0.08$ \\
JS3 $(n=3)^{\ddagger}$ & $0.47 \pm 0.22$ & $2.54 \pm 0.40$ \\
$7122(n=3)^{\ddagger}$ & $0.08 \pm 0.04$ & $2.96 \pm 1.22$ \\
\hline
\end{tabular}

${ }^{*}$ Mean $\log _{10}$ kill \pm SD for $n$ experiments.

₹ Strains for which $\log _{10}$ kill is significantly greater than without McAb 10. 


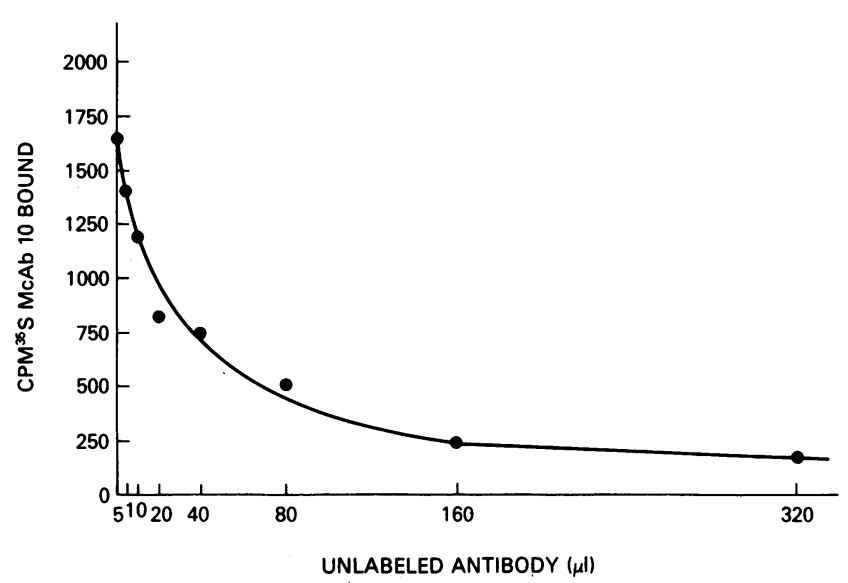

Figure 1. Inhibition of ${ }^{35} \mathrm{~S} \mathrm{McAb} 10$ binding to JS3 by unlabeled $\mathrm{McAb}$ 10. Increasing volumes of unlabeled McAb 10 were mixed with ${ }^{35} \mathrm{~S} \mathrm{McAb} 10$ and added to $1 \times 10^{6} \mathrm{JS} 3$. Mixtures were rotated end over end at $37^{\circ} \mathrm{C}$ for $1 \mathrm{~h}$, washed, and the radioactivity associated with JS3 was then measured. Unlabeled McAb 10 inhibited binding of ${ }^{35} \mathrm{~S} \mathrm{McAb} 10$ to JS3 in a dose-dependent fashion.

of the 57-kD fragment of activated C1s on autoradiograms (data not shown). E. coli $\mathrm{J} 5$, at both concentrations tested, and aggregated human IgG produced activated $\mathrm{Cl}$ s in the presence and absence of $\mathrm{Cl}$-inhibitor. These results indicate that gonococcal strain JS3 does not initiate activation of the classical complement pathway by directly activating $\mathrm{Cl}$ in the absence of other serum factors.

Classical complement pathway activation by JS3. We then tested whether JS3 would activate purified components of the classical pathway $(\mathrm{C} 1, \mathrm{C} 4, \mathrm{C} 2$, and $\mathrm{C} 3)$ in the presence of $\mathrm{McAb} 10$. Strain JS3, with or without McAb 10 presensitization, was mixed with GPC1 or reassociated human $\mathrm{Cl}$ subunits, followed by $5 \%$ serum levels of $\mathrm{C} 4, \mathrm{C} 2$, and $\mathrm{C} 3$ plus ${ }^{125} \mathrm{I}-\mathrm{C} 3$ or, in control experiments, $5 \%$ serum levels of $\mathrm{C} 4$ and $\mathrm{C} 3$ plus ${ }^{125} \mathrm{I}-\mathrm{C} 3$. Classical complement pathway activation was determined by measuring binding of ${ }^{125} \mathrm{I}-\mathrm{C} 3$ to JS3 after a 30-min incubation at $37^{\circ} \mathrm{C}$. Specific binding of ${ }^{125} \mathrm{I}-\mathrm{C} 3$ to JS3 occurred in the absence of added McAb 10, whether GPC1 or human $\mathrm{Cl}$ was used (Fig. 2). The extent of specific binding (molecules bound with $\mathrm{C} 1423$ minus molecules bound with C143) was 4,000 molecules C3/organism with GPC1 and 3,000 molecules/organism with human $\mathrm{C} 1$. When JS3 was presensitized with $\mathrm{McAb} 10$, specific binding of $\mathrm{C} 3$ remained $\sim$ 4,500 molecules of $\mathrm{C} 3$ /organism, regardless of the source of $\mathrm{C} 1$. Irrelevant MAb neither blocked nor enhanced $\mathrm{C} 3$ binding (not shown). Because antibody-independent activation of $\mathrm{Cl}$ by JS3 was excluded earlier, the C3 deposition observed in the absence of $\mathrm{McAb} 10^{\circ}$ can only be explained by the activation state of the $\mathrm{Cl}$ used in these experiments. $\mathrm{GPCl}$ is available only in activated form and is capable of activating the remaining human classical pathway components. Human $\mathrm{Cl}$ zymogen subjected to the conditions of this assay $\left(37^{\circ} \mathrm{C}\right.$ for $30 \mathrm{~min}$ ) spontaneously activates by the autocatalytic mechanism (37). In agreement with this model, when $\mathrm{Cl}$ (GPC1 or human $\mathrm{C1}$ ) and $\mathrm{Cl}$-inhibitor (both at $5 \%$ normal serum concentrations) were added to gonococci before addition of $\mathrm{C} 4, \mathrm{C} 2$, and $\mathrm{C} 3$, deposition of C3 was completely abrogated (Fig. 3). Similar results were obtained when $\mathrm{C} 1$-inhibitor was added together with $\mathrm{C} 4, \mathrm{C} 2$, and $\mathrm{C} 3$ (not shown). Experiments were then done

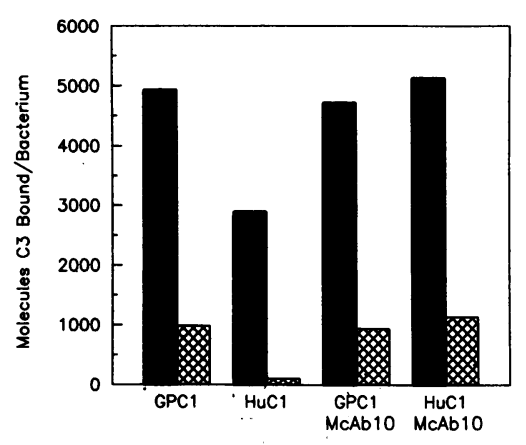

Figure 2. C3 binding to gonococci in the presence and absence of McAb 10. Strain JS3 (8 $\left.\times 10^{6}\right)$ was presensitized with McAb 10 or buffer, incubated with $\mathrm{GPCl}$ or human $\mathrm{Cl}$ at $30^{\circ} \mathrm{C}$ for $15 \mathrm{~min}$, and then washed. Human $\mathrm{C} 4, \mathrm{C} 2$, and ${ }^{125} \mathrm{I}-\mathrm{C} 3$ (solid bars) or $\mathrm{C} 4$ and ${ }^{125}$ I-C3 (hatched bars) were mixed with the cells and incubated for $15 \mathrm{~min}$ at $37^{\circ} \mathrm{C}$. Triplicate aliquots were removed, washed, and ${ }^{125} \mathrm{I}-\mathrm{C} 3$ associated with the pellet was determined. C3 deposition occurred on JS3 in the presence or absence of McAb 10 using either GPCl or human $\mathrm{Cl}$.

to determine if the $\mathrm{Cl}$ activation in the presence of $\mathrm{McAb} 10$ was also prevented by $\mathrm{C} 1$-inhibitor. JS3 pretreated with $\mathrm{McAb}$ 10 was incubated with a mixture of human $\mathrm{Cl}$ and $\mathrm{Cl}$-inhibitor, followed by $\mathrm{C} 4, \mathrm{C} 2$, and $\mathrm{C} 3$. McAb 10 completely restored $\mathrm{C} 1$ activation and $\mathrm{C} 3$ binding by JS3 (Fig. 3).

Form of $C 3$ bound to JS3. We analyzed the form of C3 deposited on JS3 with purified classical pathway components using SDS-PAGE and autoradiography. In the absence of methylamine (Fig. 4, left), C3-acceptor complexes migrating at $150,000 \mathrm{~mol} \mathrm{wt}$ and larger were observed, as well as a large amount of $\alpha(120,000), \alpha^{\prime}(110,000)$ chain, and $\beta$ chain $(75,000)$ of $\mathrm{C} 3 \mathrm{~b}$. The autoradiogram shown does not clearly demonstrate distinct $\alpha$ and $\alpha^{\prime}$ bands, but both fragments are apparent in less heavily exposed autoradiograms. No such high molecular weight $\mathrm{C} 3$-acceptor complexes were noted in lanes containing samples lacking $\mathrm{C} 2$. This reinforced earlier results showing no specific binding of $\mathrm{C} 3$ unless all classical components were present. Upon treatment with methylamine (Fig. 4, right), $\mathrm{C} 3$ was released from acceptor molecules and migrated as $\mathrm{C} 3 \mathrm{~b}$ in the form of $\mathrm{C} 3 \alpha^{\prime}$ and $\mathrm{C} 3 \beta$ chains $(110,000$ and $75,000 \mathrm{~mol} \mathrm{wt}$, respectively). No bands corresponding to the 68,000-mol wt $\alpha_{1}^{\prime}$ fragment of iC3b or the 41,000-mol wt $\alpha_{2}^{\prime}$ fragment of $\mathrm{C} 3 \mathrm{dg}$ were observed. The experiment shown was performed with GPC1, but was repeated several times using human $\mathrm{Cl}$ with the same outcome (not shown). These results indicate that a portion of $\mathrm{C} 3$ deposited with purified classical pathway components binds covalently as a portion of $\mathrm{C} 3 \mathrm{~b}$ to

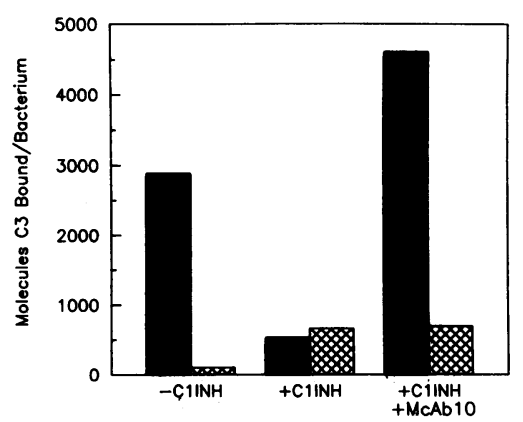

Figure 3. $\mathrm{Cl}$ activation in the presence of $\mathrm{Cl}$ inhibitor. JS3, with or without McAb 10 presensitization, was incubated at $30^{\circ} \mathrm{C}$ with a mixture of $\mathrm{C} 1$ and $\mathrm{Cl}$ inhibitor or $\mathrm{Cl}$ alone, washed, and then incubated at $37^{\circ} \mathrm{C}$ with $\mathrm{C} 4$, $\mathrm{C} 2$, and ${ }^{125} \mathrm{I}-\mathrm{C} 3$ (solid bars) or $\mathrm{C} 4$ and ${ }^{125} \mathrm{I}-\mathrm{C} 3$ (hatched bars). Cl-in-

hibitor suppressed C3 deposition on JS3 to the level seen in the absence of $\mathrm{C} 2$. McAb 10 circumvented the effects of $\mathrm{C} 1$-inhibitor, and C3 deposition was restored. 


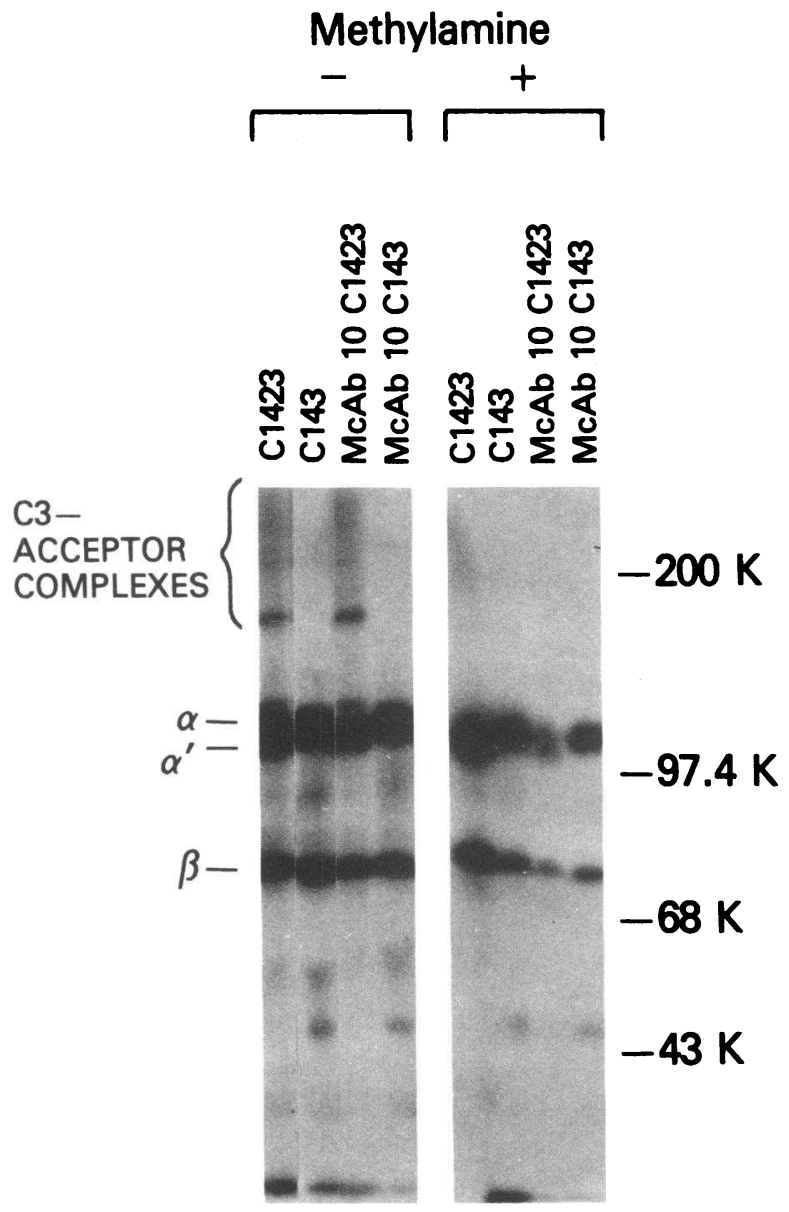

Figure 4. Autoradiogram of 7.5\% SDS-PAGE demonstrating the form of C3 bound to JS3 and the oxyester nature of the bond. JS3, with or without presensitization with McAb 10, was incubated in purified $\mathrm{C} 142^{125} \mathrm{I}-\mathrm{C} 3$ or $\mathrm{C} 14{ }^{125} \mathrm{I}-\mathrm{C} 3$ as described in Methods. Whole, washed organisms were analyzed by $7.5 \%$ SDS-PAGE autoradiography. (Left) High molecular weight C3-acceptor complexes at 150,000 mol wt and greater, along with free $\alpha, \alpha^{\prime}$, and $\beta$ chain of $\mathrm{C} 3 \mathrm{~b}$ only in samples containing a complete set of the classical pathway components. (Right) Release by methylamine of $\mathrm{C} 3 \mathrm{~b}$ in the form of $\mathrm{C} 3 \alpha^{\prime}$ $(110,000 \mathrm{~mol} \mathrm{wt})$ and $\mathrm{C} 3 \beta(75,000 \mathrm{~mol} \mathrm{wt})$. No smaller fragments not present in the pretreatment sample are apparent.

gonococcal constituents via an ester linkage, with no evidence for further cleavage.

Opsonization, phagocytosis, and killing of JS3. Gonococcal, strain JS3, preopsonized with various combinations of McAb 10 and classical complement pathway constituents, was tested in neutrophil phagocytosis and killing assays with PMN. Significant killing in comparison to buffer was noted for all combinations of opsonins tested (Table III); however, the combination of McAb 10 plus $\mathrm{C} 1423$ was significantly more bactericidal than either McAb 10 alone or McAb 10 plus C143. Although most experiments were performed using $20 \mu \mathrm{l}$ of McAb 10 for presensitization, results were not substantially different when either $5 \mu \mathrm{l}$ (34\% survival) or $80 \mu \mathrm{l}$ (25\% survival) of McAb 10 were used in conjunction with C1423.

\section{Discussion}

This paper examines the control of complement activation on the surface of $N$. gonorrhoeae. In particular, our studies have
Table III. Opsonization and Neutrophil Phagocytosis and Killing of Strain JS3 Gonococci

\begin{tabular}{|c|c|c|}
\hline Opsonin & $\begin{array}{l}\text { Amount of } \\
\text { McAb } 10\end{array}$ & Survival at $60 \mathrm{~min}^{*}$ \\
\hline & $\mu l$ & $\%$ \\
\hline Buffer & 0 & $82 \pm 16^{\ddagger}(5)$ \\
\hline $\mathrm{C} 1423$ & 0 & $43 \pm 3^{\S}$ \\
\hline McAb 10 & 20 & $51 \pm 17$ \\
\hline \multirow[t]{3}{*}{$\mathrm{C} 1423+\mathrm{McAb} 10$} & 5 & $34 \quad(2)$ \\
\hline & 20 & $30 \pm 11^{\S}(3)$ \\
\hline & 80 & $25 \quad(2)$ \\
\hline $\mathrm{C} 143+\mathrm{McAb} 10$ & 20 & $57 \pm 7$ \\
\hline
\end{tabular}

In parentheses, number of experiments performed.

* Incubation at $37^{\circ} \mathrm{C}$ in a candle-extinction jar.

"Mean \pm SD.

$\S$ Significantly different from buffer by $t$ test.

focused on the interaction of the gonococcal surface with antibody (McAb 10) directed against the H.8 antigen and with classical pathway components. We have reported in this paper that McAb 10 has differential bactericidal activity for various strains of gonococci in adsorbed PNHS. We next showed antibody-independent $\mathrm{C} 3 \mathrm{~b}$ deposition on strain JS3 gonococci via the classical complement pathway. Although addition of $\mathrm{Cl}$ inhibitor blocked this activation, McAb 10 fully restored classical pathway activation and enhanced PMN phagocytosis and killing of gonococci. We have thus demonstrated, using a system of rigorously controlled, purified complement constituents, that antibody is necessary for classical pathway activation in the presence of $\mathrm{Cl}$-inhibitor by a clinical, serum-resistant isolate of $N$. gonorrhoeae.

Complement activation is regulated in serum (and plasma) by $\mathrm{Cl}$-inhibitor. In the absence of this inhibitor, $\mathrm{Cl}$ can spontaneously autoactivate (reviewed in references 9 and 37-39). $\mathrm{Cl}$-inhibitor does not prevent $\mathrm{Cl}$ activation mediated by soluble immune complexes or by antibody-coated erythrocytes. A role for both antibody and for $\mathrm{C} 4$ in protecting activated $\mathrm{C} 1$ against inactivation by $\mathrm{Cl}$-inhibitor has been suggested (45).

A variety of substances and particles have been shown to activate $\mathrm{Cl}$ in the presence of $\mathrm{Cl}$-inhibitor, but in the absence of antibody (46-50). Various strains of gram-negative bacteria have been studied in this regard. Tenner et al. (6) showed that a strain of $E$. coli (J5) bearing rough LPS activated $\mathrm{Cl}$ directly in the presence and absence of $\mathrm{Cl}$-inhibitor. In contrast, the parent 0111B4 strain containing smooth LPS activated $\mathrm{Cl}$ in the absence, but not the presence, of $\mathrm{C} 1$-inhibitor. In this same study, Tenner provided indirect evidence that a two-site interaction of $\mathrm{Cl}$ with $E$. coli $\mathrm{J} 5$ was necessary for circumventing control of C1-inhibitor. Clas and Loos (9) made similar speculations based on their studies with purified LPS from Salmonella and from the capacity of $\mathrm{Cl}$ to interact directly with bacterial outer membrane proteins. Aubert (8) suggested that only a single-site interaction was required for $\mathrm{Cl}$ activation by $E$. coli strain D3m4. The structural requirements within LPS for direct $\mathrm{Cl}$ binding and classical pathway activation are also under study. Data of Vukajlovich and colleagues give the most lucid explanation of this problem. They suggest that Dmanno-heptulose within Salmonella LPS abrogates classical 
pathway activation (activating instead the alternative pathway) in serum $(51,52)$. Precise structural characterization of the LPS from $N$. gonorrhoeae has not been completed. The observation by Shafer et al. (4) that a "deep rough" mutant of $N$. gonorrhoeae lacking D-manno-heptose activated the classical pathway and was killed in agammaglobulinemic serum suggests that results with $N$. gonorrhoeae may be analogous to those with Salmonella.

Serum-resistant gonococci activate the classical pathway in non-immune or adsorbed human serum. Although C3 and C5b-9 are deposited on the bacterial outer membrane, killing does not occur $(14,28)$. Bactericidal rabbit polyclonal antibody alters the site of deposition or molecular configuration of C5b-9 bound to the gonococcal surface without increasing the amount of bound C5b-9 $(28,53)$. Similar results are reported for bactericidal human antibody for $N$. gonorrhoeae (53) as well as for some, but not all, murine MAb directed against the major gonococcal outer membrane protein PI (5). Such a change in form or site of binding of C5b-9 to some serum-resistant organisms is the most likely explanation for killing of serum-resistant JS3 by adsorbed PNHS supplemented with McAb 10.

The specific antibody, MAb10, enhanced neutrophil phagocytosis and killing of JS3. In the absence of serum, neutrophils avidly ingest piliated gonococci containing some but not all PII proteins $(55,56)$. In contrast, nonpiliated organisms lacking PII are not ingested in the absence of opsonization (55, 56). A rigorous dissection of the relative contribution of antibody and complement to phagocytosis of $N$. gonorrhoeae has not previously been attempted with purified opsonins. Our data suggest that both anti-H.8 IgG and $\mathrm{C} 3 \mathrm{~b}$ facilitate phagocytosis of JS3 by neutrophils, but that optimal phagocytosis is achieved with a combination of both ligands.

\section{Acknowledgments}

The authors acknowledge the valuable advice and suggestions of Dr Peter Densen and Dr. William Shafer during the course of this work.

Dr. Schweinle is recipient of a James W. McLaughlin Faculty Fellowship.

\section{References}

1. Ingwer, I., B. H. Petersen, and G. Brooks. 1978. Serum bactericidal action and activation of the classic and alternate complement pathways by Neisseria gonorrhoeae. J. Lab. Clin. Med. 92:211-218.

2. Tramont, E. C., J. C. Sadoff, and C. Wilson. 1977. Variability of the lytic susceptibility of Neisseria gonorrhoeae to human sera. J. Immunol. 118:1843-1851.

3. Schoolnik, G. K., H. D. Ochs, and T. M. Buchanan. 1979. Immunoglobulin class responsible for gonococcal bactericidal activity of normal human sera. J. Immunol. 122:1771-1779.

4. Shafer, W. M., K. Joiner, L. F. Guymon, M. S. Cohen, and P. F. Sparling. 1984. Serum sensitivity of Neisseria gonorrhoeae: the role of lipopolysaccharide. J. Infect. Dis. 149:175-183.

5. Joiner, K. A., K. A. Warren, M. Tam, and M. M. Frank. 1985. Monoclonal antibodies against gonococcal protein I vary in bactericidal activity. J. Immunol. 134:3411-3419.

6. Tenner, A. J., R. J. Ziccardi, and N. R. Cooper. 1984. Antibody independent activation of $\mathrm{Cl}$ by E. coli. J. Immunol. 133:886-891.

7. Betz, S., and H. Isliker. 1981. Antibody-independent interactions between Escherichia coli J5 and human complement components. J. Immunol. 127:1748-1754.

8. Aubert, G., S. Chesne, G. J. Arlaud, and M. G. Colomb. 1985. Antibody-independent interaction between the first component of human complement, $\mathrm{C} 1$, and the outer membrane of Escherichia coli D31m4. Biochemistry. 232:513-519.

9. Clas, F., G. Schmidt, and M. Loos. 1985. The role of the classical pathway for the bactericidal effect of normal sera against gram-negative bacteria. In Current Topics in Microbiology and Immunology. $\mathbf{M}$. Loos, editor. Springer-Verlag, Berlin/Heidelberg, FRG. 121:19-22.

10. Ziccardi, R. J. 1983. The first component of human complement (C1): activation and control. Springer Semin. Immunopathol. 6:213-230.

11. Colomb, M. G., G. J. Arlaud, and C. L. Villiers. 1984. Structure and activation of $\mathrm{C} 1$ : current concepts. Complement. 1:69-80.

12. Mandrell, R., H. Schneider, M. Apicella, W. Zollinger, P. A. Rice, and J. M. Griffiss. 1986. Antigenic and physical diversity of Neisseria gonorrhoeae lipooligosaccharide. Infect. Immun. 54:63-69.

13. Apicella, M. A. 1976. Serogrouping of Neisseria gonorrhoeae: identification of four immunologically distinct acidic polysaccharides. J. Infect. Dis. 134:377-383.

14. Harriman, G. R., E. R. Podack, A. I. Braude, L. C. Corbell, A. F. Esser, and J. G. Curd. 1982. Activation of complement by serum-resistant Neisseria gonorrhoeae. J. Exp. Med. 156:1235-1249.

15. Cannon, J. G., W. J. Black, I. Nochamkin, and P. W. Stewart. 1984. Monoclonal antibody that recognizes an outer membrane antigen common to the pathogenic Neisseria species but not to most nonpathogenic Neisseria species. Infect. Immun. 43:994-999.

16. Hitchcock, P. J., S. F. Hayes, L. W. Mayer, W. M. Shafer, and S. L. Tessier. 1985. Analysis of gonococcal H.8 antigen. Surface location, inter- and intrastrain electrophoretic heterogeneity and unusual two-dimensional electrophoretic characteristics. J. Exp. Med. 162:2017-2034.

17. Virji, M., K. Zak, and J. E. Heckels. 1985. Use of monoclonal antibody to detect common protein antigens present in outer membranes of Neisseria species. In The Pathogenic Neisseriae. G. K. Schoolnik, editor. American Society for Microbiology, Washington, DC. 276-280.

18. Zollinger, W. D., J. S. Ray, E. E. Moran, and R. Seid. 1985. Identification by monoclonal antibody of an antigen common to pathogenic Neisseria species. In The Pathogenic Neisseriae. G. K. Schoolnik, editor. American Society for Microbiology, Washington, DC. $579-584$.

19. Hitchcock, P. J., J. Boslego, K. A. Joiner, and E. N. Robinson, Jr. 1986. Analyses of the immunoaccessibility of H.8 antigen and the functionality of $\mathrm{H} .8$ specific monoclonal antibody 10 . In Fifth International Pathogenic Neisseria Conference Proceedings. J. Poolman, editor. 537-552.

20. Strittmatter, W., and P. J. Hitchcock. 1986. Isolation and preliminary biochemical characterization of the gonococcal H.8 antigen. J. Exp. Med. 164:2038-2048.

21. Gotschlich, E. C., M. S. Blake, J. M. Koomey, M. Seiff, and A. Derman. 1986. Cloning of the structural genes of three H.8 antigens and of protein III of Neisseria gonorrhoeae. J. Exp. Med. 164:868-881.

22. Aho, E. L., G. L. Murphy, and J. G. Cannon. 1987. Distribution of specific DNA sequences among pathogenic and commensal Neisseria species. Infect. Immun. 55:1009-1013.

23. Baehr, W., E. C. Gotschlich, and P. Hitchcock. 1989. The virulence-associated Neisserial H.8 gene encodes a pentapeptide sequence found in 14 tandem repeats. Mol. Microbiol. In press.

24. Kawula, T. H., S. M. Spinola, D. G. Klapper, and J. G. Cannon. 1987. Localization of a conserved epitope and an asurin-like domain in the H.8 protein of pathogenic Neisseria. Mol. Microbiol. 1:179-185.

25. Gotschlich, E. C., and M. E. Seiff. 1987. Identification and gene structure of an azurin-like protein with a lipoprotein signal peptide in Neisseria gonorrhoeae. FEMS (Fed. Eur. Microbiol. Soc.) Microbiol. Lett. 43:253-255.

26. Black, J. R., W. J. Black, and J. G. Cannon. 1985. Neisserial antigen $\mathrm{H} .8$ is immunogenic in patients with disseminated gonococcal and meningococcal infections. J. Infect. Dis. 151:650-657.

27. Black, J. R., M. Thompson, J. G. Cannon, C. Fenner, and G. F. 
Brooks. 1987. Fifth International Pathogenic Neisserial Conference. J. Poolman, editor. Elsevier Science Publishers, Amsterdam. 493-497.

28. Joiner, K. A., K. A. Warren, E. J. Brown, J. Swanson, and M. M. Frank. 1983. Studies on the mechanism of bacterial resistance to complement-mediated killing. IV. C5b-9 forms high molecular weight complexes with bacterial outer membrane constituents on serum-resistant but not on serum-sensitive Neisseria gonorrhoeae. $J$. Immunol. 131:1443-1451.

29. Gaither, T. A., and M. M. Frank. 1979. Complement. In Clinical Diagnosis and Management by Laboratory Methods. J. B. Henry, editor. W. B. Saunders Co., Philadelphia, PA. 1245-1264.

30. Swanson, J. 1978. Studies on gonococcus infection. XII. Colony color and opacity variants of gonococci. Infect. Immun. 19:320 331.

31. Tenner, A. J., P. H. Lesavre, and N. R. Cooper. 1981. Purification and radiolabeling of human C1q. J. Immunol. 127:648-653.

32. Ziccardi, R. J., and N. R. Cooper. 1976. Physiochemical and functional characterization of the $\mathrm{Cl}$ r subunit of the first complement component. J. Immunol. 116:496-503.

33. Valet, G., and N. R. Cooper. 1974. Isolation and characterization of the proenzyme form of the $\mathrm{Cls}$ subunit of the first complement component. J. Immunol. 112:339-350.

34. Hammer, C. H., G. H. Wirtz, L. Renfer, H. D. Gresham, and B. F. Tack. 1981. Large scale isolation of functionally active components of the human complement system. J. Biol. Chem. 256:39954006.

35. Prograis, L. J. Jr., C. H. Hammer, K. Katusha, and M. M. Frank. 1987. Purification of $\mathrm{Cl}$ inhibitor. A new approach for the isolation of this biologically important plasma protease inhibitor. $J$. Immunol. Methods. 99:113-122.

36. Hammer, C. H., R. M. Jacobs, C. M. Brickman, and M. M. Frank. 1987. New human complement protein which co-isolates with C2. In Abstracts XIIth International Complement Workshop. G. Arland, U. E. Nydegger, and J. Schifferli, editors. S. Karger Medical and Scientific Publishers, Basel, Switzerland. 165.

37. Ziccardi, R. J. 1982. Spontaneous activation of the first component of human complement $(\mathrm{C} 1)$ by an intramolecular autocatalytic mechanism. J. Immunol. 128:2500-2504.

38. Ziccardi, R. J. 1982. A new role for C1-inhibitor in homeostasis: control of activation of the first component of human complement. J. Immunol. 128:2505-2508.

39. Cooper, N. R. 1985. The classical complement pathway: activation and regulation of the first complement component. $A d v$. Immunol. 37:151-216.

40. Cooper, N. R., and R. J. Ziccardi. 1977. Reconstitution of C1 in nature proenzyme form and its use in a quantitative $\mathrm{Cl}$ activation test. J. Immunol. 119:1664-1667.

41. Laemmli, U. K. 1970. Cleavage of structural proteins during the assembly of the head of bacteriophage T4. Nature (Lond.). 227:680-685.
42. Swanson, J. 1981. Surface-exposed protein antigens of the gonococcal outer membrane. Infect. Immun. 34:804-816.

43. Judd, R. C. 1982. Surface peptide mapping of protein I and protein III of four strains of Neisseria gonorrhoeae. Infect. Immun. 37:632-641.

44. Swanson, J., L. W. Mayer, and M. R. Tam. 1982. Antigenicity of Neisseria gonorrhoeae outer membrane protein(s) III detected by immunoprecipitation and Western blot transfer with a monoclonal antibody. Infect. Immun. 38:668-672.

45. Tenner, A. J., and M. M. Frank. 1986. Activator-bound $\mathrm{Cl}$ is less susceptible to inactivation by $\mathrm{Cl}$-inhibitor than is fluid phase $\mathrm{Cl}$. J. Immunol. 137:625-630.

46. Storrs, S. B., W. P. Kolb, and M. S. Olson. 1983. Clq binding and $\mathrm{Cl}$ activation by various isolated cellular membranes. J. Immunol. 127:648-653.

47. Kovacsovics, T., J. Tschopp, A. Kress, and H. Isliker. 1985. Antibody-independent activation of $\mathrm{Cl}$, the first component of complement, by cardiolipin. J. Immunol. 135:2695-2700.

48. Clas, F., and M. Loos. 1981. Antibody-independent binding of the first component of complement $(\mathrm{Cl})$ and its subcomponent $\mathrm{Clq}$ to the $\mathrm{S}$ and $\mathrm{R}$ forms of Salmonella minnesota. Infect. Immun. 31:11381144.

49. Bartholomew, R. M., and A. B. Esser. 1980. Mechanism of antibody-independent activation of the first component of complement (CI) on retrovirus membranes. J. Biochem. 19:2847-2852.

50. Peitsch, M. C., T. J. Kovacsovics, J. Tschopp, and H. Isliker. 1987. Antibody-independent activation of C1. II. Evidence for two classes of nonimmune activators of the classical pathway of complement. J. Immunol. 138:1871-1876.

51. Vukajlovich, S. W. 1986. Antibody-independent activation of the classical pathway of human serum complement by lipid $A$ is restricted to Re-chemotype lipopolysaccharide and purified lipid A. Infect. Immun. 53:480-485.

52. Vukajlovich, S. W., J. Hoffman, and C. D. Morrison. 1987. Activation of human serum complement by bacterial lipopolysaccharides: structural requirements for antibody independent activation of the classical and alternative pathways. Mol. Immunol. 24:319-331.

53. Joiner, K., K. Warren, C. H. Hammer, and M. Frank. 1985. Bactericidal but not non-bactericidal C5b-9 is associated with distinctive outer membrane proteins in Neisseria gonorrhoeae. J. Immunol. 134:1920-1925.

54. Joiner, K. A., R. Scales, K. A. Warren, M. M. Frank, and P. A. Rice. 1985. Blocking immunoglobulin $\mathrm{G}$ enhances complement consumption and deposition on Neisseria gonorrhoeae. J. Clin. Invest. 76:1765-1772.

55. Fischer, S. H., and P. J. Rest. 1988. Gonococci possessing only certain P.II outer membrane proteins interact with human neutrophils. Infect. Immun. 56:1574-1579.

56. Virji, M., and J. E. Heckels. 1986. The effect of protein II and pili on the interaction of Neisseria gonorrhoeae with human polymorphonuclear leukocytes. J. Gen. Microbiol. 132:503-512. 